\title{
THE WASTE HIERARCHY: A STRATEGIC, TACTICAL AND OPERATIONAL APPROACH FOR DEVELOPING COUNTRIES. THE CASE STUDY OF MOZAMBIQUE
}

\author{
K. FERRARI, R. GAMBERINI \& B. RIMINI \\ Department of Sciences and Methods for Engineering, University of Modena and Reggio Emilia, Italy.
}

\begin{abstract}
Waste management in Europe is shaped by the waste hierarchy, which guides the legislation and policy of the Member States. This hierarchy applies the following order of priority: (1) prevention; (2) preparing for reuse; (3) recycling; (4) other recovery; (5) disposal. The wide acceptance of this principle in Europe comes from a yearly developed pathway that should not be exported to other countries without consideration of the local framework. Poverty is widespread in most African countries, with the majority of the population surviving on less than 2 US dollars a day and the average waste production per capita being about half the quantity produced in Europe. However, municipal solid waste management is still inadequate throughout the region, with open waste burning and dumping being the only method of disposal in enormous cities. These in turn arise without any planning or basic infrastructure such as roads, sewers or waste landfills. We used the case study of Mozambique to define a strategic, tactical and operational approach for the implementation of the waste hierarchy and to customize it to the local situation. Like other African countries, the major weaknesses in the performance of waste management are the poor legal framework, the lack of institutional structures and the ineffective and poorly coordinated initiatives of the international stakeholders. We propose an interpretation of the waste hierarchy in order to compensate for local deficiencies and to define a local framework for the policy makers whereby prevention is no longer a priority in the short term, in order to stress the awareness and the collection. These are consolidated steps of waste management in industrialized countries but which still pose a challenge in developing nations.
\end{abstract}

Keywords: developing countries, disposal, Mozambique, recycling, reduction, waste hierarchy, waste management.

\section{INTRODUCTION}

In 2005, the Commission of the European Communities released the thematic strategy on the prevention and recycling of waste [1], which in 2011 was evaluated by the same Commission [2]. A life-cycle approach aimed at improving waste management, diverting waste from landfill in order to minimize the pressure on the environment and reducing the lack of resources, is promoted. The strategy was presented in Directive 2006/12/EC [3] and was repealed two years later by Directive 2008/98/EC [4]. Art. 4 of the latter dedicated to Waste Hierarchy (WH), defined as a priority order in waste prevention management legislations and policies where the most preferred option should be prevention, followed by preparing for re-use, recycling, other recovery choices, and finally disposal as the least preferred option. As confirmed in 2012 by European Commission [5], the main aim of WH is not to define how member states should manage specific streams of waste to reduce landfill disposal, but to reduce the adverse impact of waste on the environment and to improve resource efficiency. Policy makers are 
invited to make reasonable choices by life-cycle thinking on the impact of waste management. This means that every choice should consider not only environmental protection but also the economic viability and the technical feasibility of the local situation. Several studies have been made on WH and various interpretative approaches by different countries and institutions were outlined, revealing contradictions and limits to be overcome [6-22].

Taking WH not as a fixed rule to be applied every where but as a universal flexible principle from which to draw inspiration to find local better solutions for waste management, we have chosen Mozambique like a case study to analyze the use and interpretation of the hierarchy principle within the legal framework. Our study draws on primary data and experiences gathered from 2011, under the waste management projects implemented by LVIA, an International non-governmental organisation based in Italy and active in Mozambique since 2006. The work was realized in partnership with the Mozambican Ministry of Land Environmental and Rural Development and the National Association of Mozambican Municipalities. First, in Section 2, we examine the Directive 2008/98/EC on waste. Next, in Section 3, we analyze the existing literature to reveal the weaknesses and limitations of the hierarchy principle. Finally, in Section 4, we look at the current waste management strategy in Mozambique, paying particular attention to how the hierarchy principle is included and interpreted by policy makers in Mozambique, as a representative case study of African developing countries. We have underlined the weaknesses and contradictions in the various definitions found, with the objective of proposing a new interpretation of the general hierarchy principle for Mozambique which should be clear, technically feasible and economically sustainable. To the best of our knowledge, this is the first piece of research aimed at understanding the interpretation of the hierarchy principle in an African developing country and could help to identify proper waste management solutions.

\section{DIRECTIVE 2008/98/EC ON WASTE}

Directive 2008/98/EC outlines principles for minimizing the adverse impact of the generation and handling of waste, reducing its negative impact on human health, the environment and the scarcity of natural resources, as emphasized by Gamberini et al. in 2014 [23]. Article 4 of the Directive is dedicated to WH and identifies five actions to be developed, in a specific order of priority, according to their relevance for correct waste management. The five actions identified are: (1) Prevention; (2) Preparing for re-use; (3) Recycling; (4) Other recovery; and (5) Disposal. The shape that best represents the hierarchy is an inverted pyramid, with the vertex upturned and divided into five horizontal layers (Fig. 1).

Although Prevention is one of the WH measures identified by the Directive, it is not a waste management measure in the proper sense because it is performed before a substance, material or product has become waste. Prevention aims to reduce the quantity of waste and/ or its adverse impact on human health and the environment.

The Directive has introduced an important evolution compared to the previous Directive 2006/12/EC on waste [3]. Preparing for re-use has been introduced as a new preferred measure for materials that have already become waste and includes checking, cleaning or repairing. Another new concept which appears in Directive 2008/98/EC is the conceptual methodology defined as Life Cycle Thinking (LCT), according to which to design waste policy it is necessary to consider the entire life cycle of the whole process, from the natural resources consumed to produce a good or service through to the production and management of waste. According to Directive 2008/98/EC, Member States can only depart from the WH if this is justified by life-cycle thinking and for particular waste streams. 


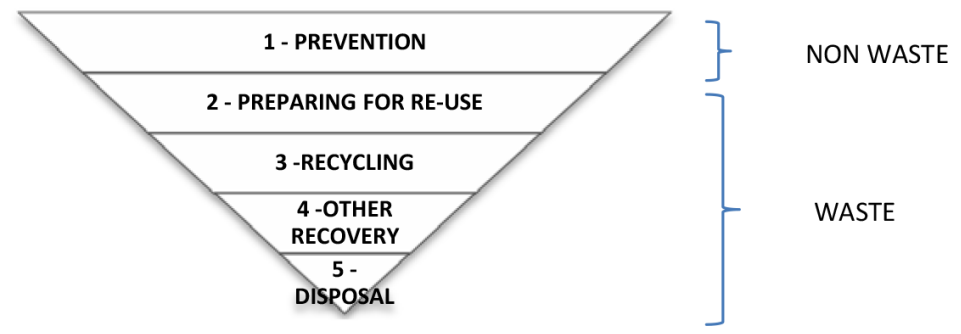

Figure 1: Illustration of WH as defined in directive 2008/98/EC.

\subsection{Results obtained in Europe due to waste hierarchy}

Data presented in a 2013 Report by EEA [24] on goals achieved by 32 European Countries concerning the management of municipal solid waste between 2001 and 2010 show a direct relationship between the cost of landfilling and the share of municipal solid waste recycled. Whereas landfilling has decreased, recycling has increased, although the total quantity of waste produced has also increased [16]. This demonstrates the important role played by landfill taxes in incentivizing a shift up the WH. Nevertheless, more than 50\% of municipal waste is still landfilled in the majority of the countries. Of course, virtuous communities exist and have been analyzed in Gamberini et al. (2013) [25].

\section{WASTE HIERARCHY, LITERATURE REVIEW OF ITS ANALYSIS}

WH is a widely accepted principle which has been interpreted and applied in waste management policies in different practical ways. It is a common belief that urban solid waste must be managed so as to mitigate its potential negative impact on the environment and human health. It is also a shared conviction that modern populations should try to become sustainable and zero-waste societies should be pursued, in accordance with circular-economy principles $[12,20,26]$.

As is clearly represented by the inverted pyramid in Fig. 1 and as was clearly cited in Ewijk \& Stegemann in 2014 [20], the WH expresses the concern in waste management by means of the objective to divert waste from landfill, especially in Europe. The lack of space for disposal sites is the main reason for diverting waste from landfills, not only in Europe but also in Japan and Korea [17]. By contrast, in the USA the key driver behind the promotion of policies aimed at shifting up the waste hierachy has been environmental crises caused by land and water contamination by hazardous waste. These have increased the interest in alternative waste managemement methods, although landfill still remains the lower cost choice [6]. In developing countries, several factors contribute to the consideration of landfill as the Best Practicable Environmental Option (BPEO), namely avaliability of space, lack of technology and financial tools to improve selective collection systems and low disposal cost [28].

Despite landfill being considered the worst waste management option by some authors $[19,21]$, according to the WH, it remains the leading disposal method in several European countries [13]. This situation does not contradict the WH, which considers this waste managemement solution to be acceptable but the worst possible choice, depending on contextual factors.

As summarized in Table 1, severeral authors consider WH to be a flawed notion $[8,10,11$, $13-15,19,20,22]$. 
Price \& Joseph (2000), Fisher (2011), Van Ewijk \& Stegemann (2014) and Tunesi (2014) state that WH is an inefficient means of promoting the reduction of waste [10, 16, 20, 21]. Price \& Joseph (2000) believe that waste reduction requires a cultural and social transformation toward a change in demand by consumers [10]. Reduction has to be thought about before buying or using a product. Van Ewijk \& Stegemann (2014) have identified as a conceptual problem of the WH the inclusion of prevention in a tool meant for waste managers, although

Table 1: Litarature review about waste hierarchy.

Authors

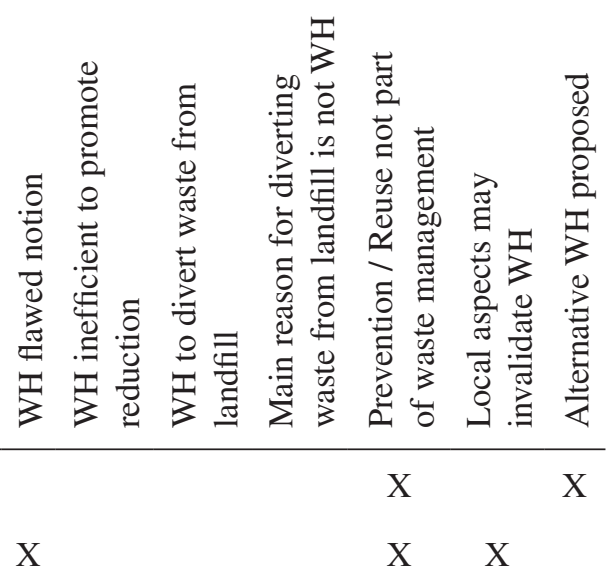

US Congress Office of Technology

X $\quad \mathrm{X}$

Assessment, 1989 [8]

Waite R., 1995 [9]

X

Price L. J. \& Joseph B. J., 2000 [10]

X $\quad X$

$\mathrm{X}$

Wilkinson D., 2002 [11]

X

Kijak R. \& Moy D., 2004 [12]

DijkgraafE. \&Vollebergh H., 2004 [13]

X

X $\quad X$

Cleary J., 2009 [14]

$\mathrm{X}$

DEFRA, 2011 [15]

$\mathrm{X}$

Fisher C., 2011 [16]

X

Sakai S. et al., 2011 [17]

$\mathrm{X}$

WRAP, 2011 [18]

Hultman J. \& Corvellec H., 2012 [19]

$\mathrm{X}$

Ewijk, S. Van, \& Stegemann, J. A., 2014 [20] $\quad$ X $\quad$ X $\quad$ X

X $\mathrm{X}$

Tunesi S., 2014 [21]

$\mathrm{X}$

Gharfalkar M. et al., 2015 [22]

$\mathrm{X}$

X 
this prevention affects materials and processes before they become waste, as is clearly illustrated by the hierarchy pyramid as drawn in Directive 2008/98/EC [20].

To avoid mistakes, the same authors consider it important to evaluate the starting situation before targeting prevention. This opinion is also shared by other authors who believe that social and economic local aspects may invalidate WH $[8-10,12,19]$. The BPEO has to be found for each case, using appropriate tools such as Life Cycle Assessment (LCA). This is considered to be a valid instrument by which to assess the best waste managemement approach, even if it sometimes reveals weaknesses [12]. A recent study of Gharfalkar et al. (2015) proposes an alternative pyramid to illustrate WH, trying to overcome the overlap and flaws of Directive 2008/98/EC [22]. The study has included the measures of reuse and recovery in an alternative hierarchy called HRU - Hierarchy of Resources Use, which considers waste as a resource. The steps defined by the authors, from the most preferred to the least preferred option are: (1) Replacement - substitutes the position occupied by Prevention in Directive 2008/98/EC and includes all operations aimed at rethinking, reinventing or redesigningin order to replace the original demand for products with a new demand that has a lower environmental impact; (2) Reduction - introduced with the objective of redesigning products or processes to reduce the use of resources; (3) Recovery was introduced and includes four different measures: preparing for reuse; reuse; reprocessing (recycling, up-cycling and down-cycling); other recoveries of energy and/or materials; (4) Rectificationtreatment before disposal; (5) Return - disposal.

\section{THE CASE STUDY OF MOZAMBIQUE}

The Republic of Mozambique is situated in southern Africa. The country is bordered by the Indian Ocean to the east, Tanzania to the north, Malawi and Zambia to the northwest, Zimbabwe to the west and Swaziland and South Africa to the southwest. Despite the positive growth rate enjoyed by Mozambique in recent years, which reached 7\% in 2015, and the increase of 5.9\% in its Gross Domestic Product (GDP), Mozambique is still one of the poorest countries in the world, with a Human Development Index (HDI) of 180 out of 188 countries and territories considered in 2014 [28]. Since gaining independence from Portugal in 1974, Mozambique suffered a 10-year civil war which ended in 1992. Because of the war, the rural population sought refuge in the cities, which have grown without any planning or proper urban infrastructure. Particularly in the capital, Maputo, new neighborhoods have sprung up spontaneously, devoid of streets, sewers and basic hygienic services [29].

\subsection{Solid waste management: a brief overview from the civil war to the present day}

In the course of the civil war, the management of urban waste was unorganized and unstructured, because neither urban sanitation nor solid urban waste management were a priority. In 1997, with the foundation of the autarchies aimed at promoting the decentralization of power, municipalities also had to assume responsibility for waste management [30, 31], even though they were not prepared to perform the new tasks. Waste was collected in a discontinuous and less efficient way by the municipality and deposited in open dumps. In Maputo, the capital of Mozambique, the Hulene municipal dump covers an area of 17 hectares and was built in 1972. It is located $7 \mathrm{~km}$ from the city center inside a heavily populated neighborhood. Today, the project for a new sanitary landfill with a total capacity of 1000 tonnes/day is ready and should be implemented in 2016, since the Hulene dump has already reached the end of its lifespan and poses a serious threat to the environment and human health [30]. 
We have analyzed all the technical and legal documentation made available by the local institutions, and we have visited many of the 53 municipalities, distributed in the national territory. None of them has a suitable location for the disposal of urban waste. Each municipality only has one or more open dumps, where all the urban waste is deposited untreated. Although some urban waste is collected and deposited in municipal authorized dumps, a significant proportion is still burned or dumped improperly in the field and streets. Once ready, the Maputo sanitary landfill will be the first in the country.

\subsection{WH in legal framework of Mozambique}

The main laws and regulations relating to the management of waste in Mozambique, which have been analyzed to understand if the WH is contemplated by Mozambican policy makers, are the following:

- Environmental Law N. 20/97;

- Regulation on Solid Waste Management, Decree N.13/2006 revoked by Decree N. 94/2014;

- National Strategy for integrated urban solid waste management (2012);

- Regulation for the management of hazardous waste, Decree 83/2014.

A definition of waste is found, for the first time, in Environmental Law N.20/97, but no mention is made about reduction, reuse or recycling [32].

The first legal instrument for waste management in Mozambique is Decree N.13/2006 [33]. Art. 1 defines as 'exploitation or recovery' the use of waste or parts thereof by processes such as refining, recovery, regeneration, recycling, reusing or other actions aimed at obtaining secondary raw materials. In the same article, reducing, recycling and reusing are mentioned in the same order as necessary measures for a correct waste management. No reference is made to $\mathrm{WH}$ or to any other priority order between the above-mentioned measures. Decree N. 13/2006 was revoked in 2014 by the new regulation about solid waste management, published by Decree ${ }^{\circ}$. 94/2014 [34], where only two processes are identified for waste management: recycling and reusing. Refining, recovery and regeneration were omitted. In Art. 4, we find the hierarchy principle for the first time among the general principles of waste management, with the following order of waste management options: prevention and reduction, reusing, recycling and other forms of recovery or disposal. The preferred option is defined as the one that uses the best available technologies at sustainable cost.

The primary strategic national document about waste management in Mozambique was finalized in 2012 [35]. For the first time, it clearly introduces the principle of the 3Rs Reduction, Reusing and Recycling and WH, that should be apply; however, it does not explain how. According to the strategy, the correct final destination for waste could be one of the following: (1) open dump with uncontrolled burning, which is accepted as the most common choice in Mozambique, although sanitary and environmental risks are recognized; (2) controlled landfill, which guarantees daily covering of waste by a layer of inert material and drainage; (3) sanitary landfill.

As far as we know, only 11 of the 53 municipalities already have a municipal plan for waste management or at least a draft of it. WH and 3Rs principles are mentioned only in four plans, but are not clearly defined. The other municipal waste management plans recognize the 
importance of the current informal recycling activities but delegate them to the spontaneous initiative of associations, projects and informal sector.

\section{RESULTS AND DISCUSSION}

Analysis of the relevant legal and strategic documentation available about waste management, and previously cited, shows that Mozambican policy-makers understand the WH and 3Rs principles, which to some extent have been introduced in key national tools. Notwithstanding that waste management policies may differ among countries due to the local situation, opportunity and constraints, as also stated by Sakai et al. in 2011 [17], we cannot deny that in Mozambican documentation the definition of WH is unclear. The priority order between prevention, reduction, reusing, recycling and other forms of recovery or disposal does not seem to be relevant because the preferred option is deemed to be the one that uses the best available technologies at sustainable cost.

Table 2: Qualitative and quantitative analysis of waste management data in 11 Mozambican municipalities.

\begin{tabular}{|c|c|c|c|c|c|c|c|c|c|c|c|c|c|}
\hline 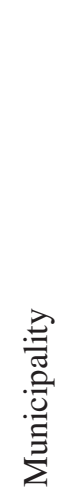 & 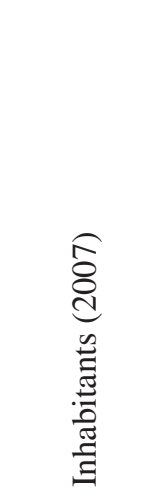 & 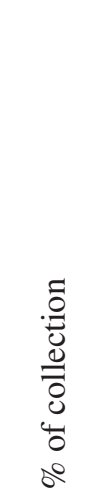 & 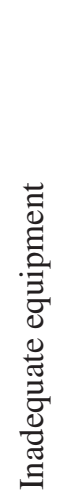 & 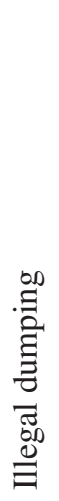 & 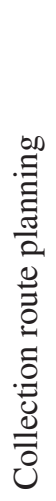 & 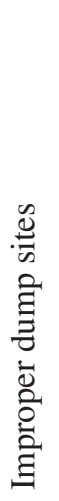 & 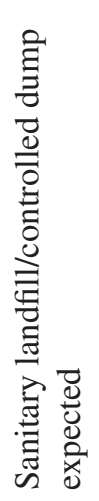 & 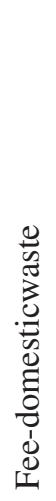 & 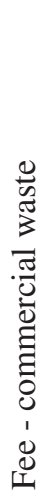 & 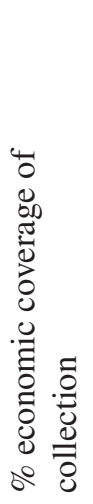 & 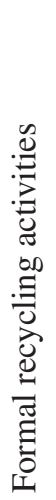 & 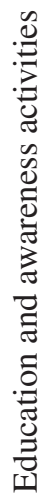 & 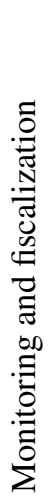 \\
\hline 1 & 1.111 .638 & 77.55 & & $\mathrm{x}$ & $\mathrm{x}$ & $\mathrm{x}$ & $\mathrm{x}$ & $\mathrm{x}$ & $\mathrm{x}$ & 90 & $\mathrm{x}$ & $\mathrm{x}$ & $\mathrm{x}$ \\
\hline 2 & 141.724 & & $\mathrm{x}$ & $\mathrm{x}$ & & & & $\mathrm{x}$ & & - & & & \\
\hline 3 & 48.063 & 40.36 & $\mathrm{x}$ & $\mathrm{x}$ & $\mathrm{x}$ & $\mathrm{x}$ & & $\mathrm{x}$ & & 10 & & & \\
\hline 4 & 206.449 & 38.18 & & $\mathrm{x}$ & & $\mathrm{x}$ & & $\mathrm{x}$ & & 16 & & & \\
\hline 5 & 193.343 & 34.48 & $\mathrm{x}$ & $\mathrm{x}$ & & $\mathrm{x}$ & $\mathrm{x}$ & $\mathrm{x}$ & & 49 & & & \\
\hline 6 & 87.889 & 35.45 & & $\mathrm{x}$ & $\mathrm{x}$ & & $\mathrm{x}$ & $\mathrm{x}$ & & 37 & & $\mathrm{x}$ & $\mathrm{x}$ \\
\hline 7 & 138.716 & 56.98 & & $\mathrm{x}$ & & $\mathrm{x}$ & $\mathrm{x}$ & $\mathrm{x}$ & & 13 & & $\mathrm{x}$ & \\
\hline 8 & 81.454 & & $\mathrm{x}$ & $\mathrm{x}$ & & $\mathrm{x}$ & & $\mathrm{x}$ & & & $\mathrm{x}$ & & \\
\hline 9 & 65.173 & 28.42 & $\mathrm{x}$ & $\mathrm{x}$ & & $\mathrm{x}$ & & $\mathrm{x}$ & $\mathrm{x}$ & 14 & $\mathrm{x}$ & & \\
\hline 10 & 16.165 & & $\mathrm{x}$ & $\mathrm{x}$ & & $\mathrm{x}$ & $\mathrm{x}$ & $\mathrm{x}$ & & & & & \\
\hline 11 & 200.000 & & $\mathrm{x}$ & & $\mathrm{x}$ & & & $\mathrm{x}$ & $\mathrm{x}$ & & & & \\
\hline
\end{tabular}


According to the data and information collected during the site visits and the study of the available documentation (Table 2), only 11 municipalities out of 53 have already adopted a waste management plan.

With the exception of the capital, the plans report approximate and insufficient data about the amount of waste generated and collected and their gravimetric composition. The percentage of waste collected by the municipalities varies between $28 \%$ and $56 \%$. All the municipalities collected a domestic waste fee, but only in three of them a greater fee for commercial producer exists. In nearly most of the municipalities, the waste fee is collected through the electricity invoice, but does not cover the total expenses incurred for the collection of waste. All the municipalities have reported serious problems with the illegal dump of waste. With the exception of Maputo, they are lacking of education and awareness programmes about the waste management and need a better monitoring and fiscalization system. Only in tree municipalities some formal recycling activity is implemented.

Before we studied all the documentation and data collected, then we tried to clarify the WH principle as it is applied in Mozambique and to analyze how each WH measure would impact on waste management, proposing a specific interpretation of the hierarchy for Mozambique, as a case study representative of developing countries. Reducing the quantity of waste produced is certainly an overall priority, but industrialized societies should be mainly responsible for reducing consumption and changing life styles [21]. Mozambique population has a poor consumer profile, far from European patterns of consumption.

Reuse in a developing and poor country is a natural operation performed every day by everyone, without awareness that this informal activity could be a component of a WH principle. On the other hand, preparing for reuse takes place, informally again, due to the activity of scavengers. As several authors [27, 36-41] have stressed, scavengers make an important contribution to waste management in developing countries by means of the survival activity of picking up waste in dumps or streets.

Two surveys to Maputo scavengers were realized in 2013 and 2014, aiming at understand the informal activity of collection and reselling of recycling waste [37]. Data were collected about the quantity and type of material collected, selling prices, storage and selling informal places and have been used to understand the informal recycling industry of Maputo, as representative of the country. Recycling is the more common option chosen by Mozambicans to divert waste from open or controlled dumping and burning, but it is not yet supported by any financial mechanism. The only economic gain by recycling is the lower cost of raw materials, which in Mozambique are imported and whose price and availability fluctuates wildly. The local recycling market is weak and mainly informal with little demand for selected waste due to the low number of local factories required to process the material into secondary raw material. The only materials recycled locally are some types of plastic (PE-Polyethylene, PP-Polypropylene), paper (but not constantly), organic waste to make compost (small amounts) and aluminium (informal sector). Other materials eventually collected are exported (PET, glass, metals).

To the best of our knowledge, energy recovery from waste is not developed in Mozambique, with the exception of some sporadic pilot experiences financed by international stakeholders.

The local situation, dominated by a scarcity of financial resources, limited availability of knowledge and technological means and an abundance of space, prompts waste management to lean toward land filling. Alternatively, we propose a new WH concept for Mozambique, 
also available and adaptable for other developing countries, characterized by the following measures in order of priority: (1) Raising - collection, focused on the awareness toward the importance of managing waste by means of a systematic approach, rather than by self-managed initiatives; (2) Sorting - as a preparatory operation prior to subsequent reuse and recycling, in order to valorize and assign the correct final destination to each material; (3) Reuse; (4) Recycling; (5) Disposal. This WH could support the optimization of collection, rather than diffusing its perception as a bottleneck and useless activity, to valorize and formalize recycling, considering disposal as not the preferred option but the most acceptable alternative to open dumping and burning.

\section{CONCLUSIONS}

In the long term, the global spread of $\mathrm{WH}$ as a general principle could guarantee that all countries move toward a circular economy where resources are used in a more sustainable way. Each country has to define its waste management strategy, customizing it to the local situation, taking into account cultural, socio-economic and environmental aspects. Like many developing countries, Mozambique is faced with the major challenge of managing increasing quantities of waste with few resources and little experience. The abundance of space for depositing the waste and the limited costs required make landfilling the preferred option of waste management. Reusing, considered as a preventive measure to be performed before the material becomes waste, is carried out informally. The informal sector overcomes also for recycling and reuse, without any incentive from policy makers, who recognize the contribution made by informal waste pickers but do not support their activities financially. Moreover, such activities are carried out under poor conditions, leading to severe risks to the environment and health. An alternative hierarchy is proposed in this paper, in order to improve waste management in a feasible way for the local situation. The most urgent challenge in Mozambique is to create greater awareness among the population of the risk posed by a deficient waste management system, to increase the quantity collected and sorted to be reused, recycled or even recovered and, finally, disposed of in a controlled space. Like any hierarchy, the WH proposed is a principle which serves as a guideline on preferred measures which themselves could vary according to local aspects. Further research is directed to collect and elaborate data to support the waste hierarchy proposed by means of a LCA - Life Cycle Assessment study, in order to also ascertain technological or practical options that in Mozambique everyday life could deliver the best overall environmental, human health, economic and social impacts.

\section{ACKNOWLEDGMENTS}

We greatly acknowledge the support of the Ministry of Land Environmental and Rural Development of Mozambique, the National Association of Mozambican Municipalities and LVIA, for the support during the site visits and allowing the use of the data collected in the framework of the project "PROSIGRU" co-financed by the Italian Ministry of Foreign Affairs and International Cooperation, and the project "Promoção da Proteção Social e Trabalho informal no Seio da população de Rua" co-financed by the European Commission.

\section{REFERENCES}

[1] Commission of the European Communities, Communication -Taking sustainable use of resources forward: A Thematic Strategy on the prevention and recycling of waste, 2005, available at: www.eur-lex.europa.eu/legal-content 
[2] Commission of the European Communities, Report on the Thematic Strategy on the Prevention and Recycling of Waste, 2011, available at: www.ec.europa.eu/environment/ waste/pdf/Progess\%20report.pdf

[3] European Parliament and of the Council of the European Union, Directive 2006/12/ EC on waste, 2006, available at: http://eur-lex.europa.eu/legal-content/EN/ TXT/?uri=CELEX\%3A32006L0012

[4] European Parliament and of the Council of the European Union, Directive 2008/98/EC on waste and repealing certain Directives, 2008, available at: http://eur-lex.europa.eu/ legal-content/EN/TXT/?uri=CELEX:32008L0098

[5] European Commission, Guidance on the interpretation of key provisions of Directive 2008/98/EC on waste, 2012, available at: http://ec.europa.eu/environment/waste/framework/pdf/guidance_doc.pdf

[6] Wolf, K., Source reduction and the waste management hierarchy.Air \& Waste Management Association, 38(5), pp. 681-686, 1988. http://dx.doi.org/10.1080/08940630.1988.10466411

[7] Wolf, K., Source Reduction and the Waste Management Hierarchy, JAPCA, Currently known as Journal of the Air \& Waste Management Association, 2012.

[8] U.S. Congress, Office of Technology Assessment, Facing America's Trash: What Next for Municipal Solid Waste? U.S. Government Printing Office, 1989.

[9] Waite R., Household waste recycling.Environment Management,Earthscan, 1995.

[10] Price, J.L. \& Joseph, J.B., Demand management-a basis for waste policy: applicability of the WH in terms of achieving sustainable waste management, Sustainable Development, 2000.

[11] Wilkinson, D., Waste Law -Waste in Ecological Economics, Edward Elgar Publishing, 2002.

[12] Kijak, R. \& Moy, D., A decision support framework for sustainable waste management. Journal of Industrial Ecology, 8(3), pp. 33-50, 2004. http://dx.doi.org/10.1162/1088198042442306

[13] Dijkgraaf, E. \& Vollebergh, H.R.J., Burn or bury? A social cost comparison of final waste disposal methods, Ecological Economics, 50(3-4), pp. 233-247, 2004. http://dx.doi.org/10.1016/j.ecolecon.2004.03.029

[14] Cleary, J., Life cycle assessments of municipal solid waste management systems: A comparative analysis of selected peer-reviewed literature.Environment International,35(8), 1256-1266, 2009. http://dx.doi.org/10.1016/j.envint.2009.07.009

[15] DEFRA, Applying the WH: evidence summary, 2011, available at: www.defra.gov.uk

[16] Fischer, C., The development and achievements of EU waste policy.Journal of Material Cycles Waste Management, 13(1), pp. 2-9, 2011. http://dx.doi.org/10.1007/s10163-010-0311-z

[17] Sakai, S., Yoshida, H., Hirai, Y., Asari, M., Takigami, H., Takahashi, S., Tomoda, K., Peeler, M.V., Wejchert, J., Schmid-Unterseh, T., Douvan, A.R., Hathaway, R., Hylander, L.D., Fischer, C., Oh, G.J., Jinhui, L. \& Chi, N.K., International comparative study of 3R and waste management policy developments.Journal of Material Cycles Waste Management, 13(2), pp. 86-102, 2011. http://dx.doi.org/10.1007/s10163-011-0009-x

[18] WRAP, Waste Hierarchy Guide. Applying the Waste hierarchy: a guide to business, available at: http://www.wrap.org.uk, 2011. 
[19] Hultman, J. \& Corvellec, H., The European WH: from the sociomateriality of waste to a politics of consumption.Environmental and Planning, 44(10), pp. 2413-2427, 2012.

[20] VanEwijk,S. \& Stegemann, J.A., Limitations of the WH for achieving absolute reductions in material throughput.Journal of Cleaner Production, 2014

[21] Tunesi, S., Conservare il valore. L'industria del recupero e il futuro della comunità, Luiss University Press, 2014.

[22] Gharfalkar, M., Court, R., Campbell, C., Ali, Z. \& Hillier, G., Analysis of WH in the European waste directive 2008/98/EC. Waste Management, 39, pp. 305-313, 2015. http://dx.doi.org/10.1016/j.wasman.2015.02.007

[23] Gamberini, R., Galloni, L., Rimini, B. \& Luppi, M., Post-consumer textile waste re-use: main steps of a sustainable process. In Proceedings of XIX Summer School "Francesco Turco", 2014.

[24] EEA, Managing municipal solid waste - a review of achievements in 32 European countries, available at: http://www.eea.europa.eu, 2013.

[25] Gamberini, R., Del Buono, D., Lolli, F. \& Rimini, B., Municipal solid waste management: Identification and analysis of engineering indexes representing demand and costs generated in virtuous Italian communities. Waste Management, 33(11), pp. 2532-2540, 2013. http://dx.doi.org/10.1016/j.wasman.2013.06.003

[26] UNEP-United Nations Environment Programme, Waste - Investing in energy and resource efficiency. In Towards a Green Economy,available at: http://web.unep.org/ greeneconomy/resources/green-economy-report, 2011.

[27] Agamuthu, P., Landfilling in developing countries. Waste Management \& Research, 31(1), pp. 1-2, 2013.

http://dx.doi.org/10.1177/0734242X12469169

[28] UNDP-United Nations Development Programme, Human development report 2015 Work for human development Mozambique,available at: http://hdr.undp.org/en/countries/profiles/MOZ, 2015.

[29] Ribeiro, H. \& Buque, L., Legislation and legal framework of urban solid waste management in Mozambique.R. Dir. Sanit. São Paulo, 2014.

[30] Alexandrino, J.M. \& Luís, S.L., Legislação de direito municipal dos sistemas de língua portuguesa.Instituto de Ciência Juridico-Política Faculdade de Direito da, universidade de Lisboa, 2014.

[31] República de Moçambique, Lei de base das autarquias N. 2/97,available at: http://www. dno.gov.mz/\#, 1997.

[32] Assembleia da República, Lei N.20/97, Boletim da Repùblica de Moçambique, 1997.

[33] República de Moçambique, Conselho de Ministros, Regulamento sobre a Gestão de Resíduos, Decreto 13/2006, Boletim da Repùblica de Moçambique, 2006.

[34] República de Moçambique, Regulamento sobre a Gestão de Resíduos Sólidos Urbanos, Decreto 94/2014, Boletim da Repùblica de Moçambique, 2014.

[35] República de Moçambique, Ministério para a Coordenação da Acção Ambiental. Estratégia de gestão integrada de resíduos sólidos urbanos em moçambique, Boletim da Repùblica de Moçambique, 2012.

[36] Downs, M.\& Medina, M., A brief history of scavenging,In Comparative Civilizations Review, COLEF, Chula Vista, California, 2000.

[37] Mertanen S.T., Langa M.J. \& Ferrari, K., Catadores de Lixo de Maputo. Quem são e como trabalham? LVIA, 2013. 
[38] Rockson, K., Kemausuor, F., Seassey, R. \& Yanful, E., Activities of scavengers and itinerant buyers in Greater Accra, Ghana.Habitat International, 39, pp. 148-155, 2013. http://dx.doi.org/10.1016/j.habitatint.2012.11.008

[39] Sembiring, E. \& Nitivattananon, V., Sustainable solid waste management toward an inclusive society: Integration of the informal sector.Resources, Conservation and Recycling, 54, pp. 802-809, 2010.

http://dx.doi.org/10.1016/j.resconrec.2009.12.010

[40] Troschinetz, A.M. \& Mihelcic, J.R., Sustainable recycling of municipal solid waste in developing countries. Waste Management, 29(2), pp. 915-923, 2009. http://dx.doi.org/10.1016/j.wasman.2008.04.016

[41] Wilson, D.C., Velis, C. \& Cheeseman, C., Role of informal sector recycling in waste management in developing countries. Habitat International, 30(4), pp. 797-808, 2006. http://dx.doi.org/10.1016/j.habitatint.2005.09.005 